doso en la 1

ar ejemplos a

is funcionalidac uso, dependiende encarnan los conceptos detr por e $\Lambda$ influ
$\mathrm{Pe}$ infin:

Las formas $d r$ oceso de sig ialidad .

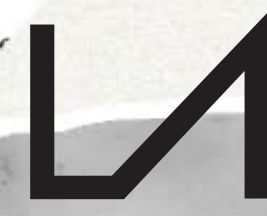

R E V I S A
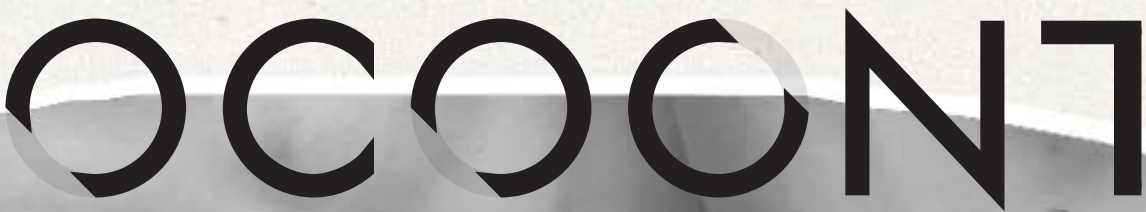

D $E$

No $6 \cdot 2019 \cdot$ ISSN 2386-8449

"El producto del diseñador es un proyecto, el estado previo de un objeto", Entrevista con Norberto Chaves, por Fernando Infante

El papel de la investigación y la teoría en diseño. Una conversación abierta, por Fernando Infante y María Jesús Godoy

UT PICTURA POESIS

Abandonar la escritura. Poesía experimental y manifiesta, Ignacio Gómez de Liaño

PANORAMA: FILOSOFÍA DEL DISEÑO Sección coordinada por Fernando Infante y María Jesús Godoy

Pensar el diseño, Fernando Infante y María Jesús Godoy (Coordinadores)

TEXTOS INVITADOS

Estatus y estado del điseño más allá del objeto, Pedro Medina Reinón

Mar de Nubes, Cuerpo de Cristal, Dionisio González

ARTÍCULOS

Understanding Design Aesthetics beyond Functional Beauty accounts, Lucía Jiménez Sánchez

Estética y diseño industrial: debates y controversias, Joan M. Marín

Del ornamento al delito. El diseño y la sociedad en Charles Baudelaire y Adolf Loos, Jorge López Lloret

When is Architecture not Design? Saul Fisher

Diseño y habitabilidad: una aproximación basada en los lenguajes de patrones, Antonio Hidalgo Pérez

Marcel Breuer: un diseñador global. Experiencias en el ámbito de la vivienda prefabricada, Salvador J. Sanchis, Ignacio Peris y Pedro Ponce Diseño y artes escénicas: el papel de Oskar Schlemmer en Das Triadische Ballett y la actualidad de la Bauhaus, Milagros García Vázquez Lo performativo en prácticas de arte y diseño actuales vinculadas a procesos de innovación social. El caso de La Venezia che non si vede y de La borda, Tània Costa Gomez

Articulaciones de la estética y el diseño. El caso de la evaluación a partir de la investigación dirigida en la carrera de diseño escénico de la Universidad de las Artes de Cuba, Mara Rodríguez Venegas y Xiomara Romero Rojas

SUPLEMENTO

El diseño, la ciudad y un lápiz de labios, Mercedes Espiau, Mar García Ranedo y Alejandro Rojas mas. 


\section{UつCつCNTE}

No $6 \cdot 2019 \cdot \operatorname{ISSN} 2386-8449 \cdot$ DOI 10.7203/LAOCOONTE.5.15381

https://ojs.uv.es/index.php/LAOCOONTE/index

COORDINACIÓN EDITORIAL

Anacleto Ferrer (Universitat de València)

Francesc Jesús Hernàndez i Dobon (Universitat de València)

Fernando Infante del Rosal (Universidad de Sevilla)

SECRETARÍA DE REDACCIÓN

Lurdes Valls Crespo (Universitat de València)

Vanessa Vidal Mayor (Universitat de València)

COMITÉ DE REDACCIÓN

Tamara Djermanović (Universitat Pompeu Fabra), Rosa Fernández Gómez (Universidad de Málaga), Anacleto Ferrer (Universitat de València), Ilia Galán (Universidad Carlos III), Ana María García Varas (Universidad de Zaragoza), María Jesús Godoy (Universidad de Sevilla), Fernando Infante del Rosal (Universidad de Sevilla), Miguel Ángel Rivero (Universidad de Sevilla), Miguel Salmerón (Universidad Autónoma de Madrid), Gerard Vilar (Universitat Autònoma de Barcelona).

COMITÉ CIENTÍFICO INTERNACIONAL

Rafael Argullol* (Universitat Pompeu Fabra), Luis Camnitzer (State University of New York), José Bragança de Miranda (Universidade Nova de Lisboa), Bruno Corà (Università di Cassino), Román de la Calle* (Universitat de València), Eberhard Geisler (Johannes Gutenberg-Universität Mainz), José Jiménez* (Universidad Autónoma de Madrid), Jacinto Lageira (Université Paris 1 Panthéon-Sorbonne), Bernard Marcadé (École Nationale Supérieure d'Arts de Paris-Cergy), Elena Oliveras (Universidad de Buenos Aires y Universidad del Salvador), Pablo Oyarzun (Universidad de Chile), Francisca Pérez Carreño* (Universidad de Murcia), Bernardo Pinto de Almeida (Faculdade de Belas Artes da Universidade do Porto), Luigi Russo (Università di Palermo), Georges Sebbag (Doctor en Filosofía e historiador del surrealismo), Zoltán Somhegyi (University of Sharjah, United Arab Emirates), Robert Wilkinson (Open University-Scotland), Martín Zubiria (Universidad Nacional de Cuyo). *Miembros de la Sociedad Española de Estética y Teoría de las Artes, SEyTA

\begin{tabular}{lll}
\hline DIRECCIÓN DE ARTE & REVISIÓN DE TEXTOS & TRANSCRIPCIÓN DE TEXTOS \\
El golpe. Cultura del entorno & Antonio Cuesta & Álvaro G. Serna
\end{tabular}

(cc) BY Excepto que se establezca de otra forma, el contenido de esta revista cuenta con una licencia Creative Commons Atribución 3.0 España, que puede consultarse en http://creativecommons.org/licenses/by/3.0/es/deed.es

EDITA

\section{SEyTA.}

CON LA COLABORACIÓN DE

\begin{tabular}{|c|c|c|c|}
\hline $\begin{array}{l}\text { VNIVERSITAT } \\
\text { ID VALENCIA } \\
\text { Institut a Creativitat } \\
\text { i|nnovacions Educatives }\end{array}$ & $\begin{array}{l}\text { VNIVERSITAT } \\
\text { IE ÖVALENCIA Departament de Filosofia }\end{array}$ & 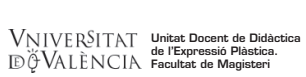 & \\
\hline $\begin{array}{l}\text { DEPARTAMENTO DE ESTÉTICA } \\
\text { E HISTORIA DE LA FILOSOFIA }\end{array}$ & $\frac{\text { UAW }}{\frac{\text { UNIVERSIDAD AUTONOMA }}{\text { DE MADRID }}}$ & $\begin{array}{l}\text { AB } \\
\text { Universitat Autònoma } \\
\text { de Barcelona }\end{array}$ & 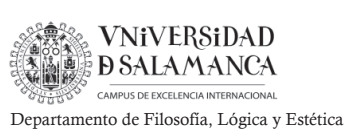 \\
\hline
\end{tabular}

LAOCOONTE aparece en los catálogos: 


\section{LつCつCN7E}

"Cuanto más penetramos en una obra de arte más pensamientos suscita ella en nosotros, y cuantos más pensamientos suscite tanto más debemos creer que estamos penetrando en ella".

G. E. Lessing, Laocoonte o los límites entre la pintura y la poesía, 1766.

Vo hay cól.

létodo, de pen.

:ión en general. Ith

zar la forma para el $\mathrm{n}$.

eptual por las orígenes

la, el objeto, la exposición

storia, porque existe en el $\mathrm{m}$

das sus raíces. Desde alli cc _. panoram

n conceptual y donde el émencia del con 'iseñado, como es el a al objeto y el di $\begin{array}{ll}\text { igen } \mathrm{de}^{\text {to }} \text { la inmer } & \text { tolvidada, o comc } \\ \text { trozo de madera ar }\end{array}$ a manera dorm comunicar ene nundo. Seguin? sngo en manos te el método $C$ les. A partir c teria prima $\mathrm{p}_{\mathbf{c}}$

'xto se puede:

¿ño, en proyea

amientos de $\mathrm{u}$

a conscie-

.)

en la publicación jue "plos de la impor te las nalidades porqu ura un ${ }^{2}$ diendo de qui zenerar $\mathrm{u}$ ción de nr? lne

in-

n-

is.

le http:,

le crear visualidades. A partir de.

ellas la propia materia prima para un en que desde un texto se puede generar $u_{11}$ i

Pensar en diseño, en proyección de nue

posibles comportamientos de una colecti

presente como una consciencia del hecho que estamos elaborando, significac

nuestro entorno (..)

Cardoso, R. C. Rafael. (2014). Design para um mundo complexo. Sãc asil: Cosac Naify. 


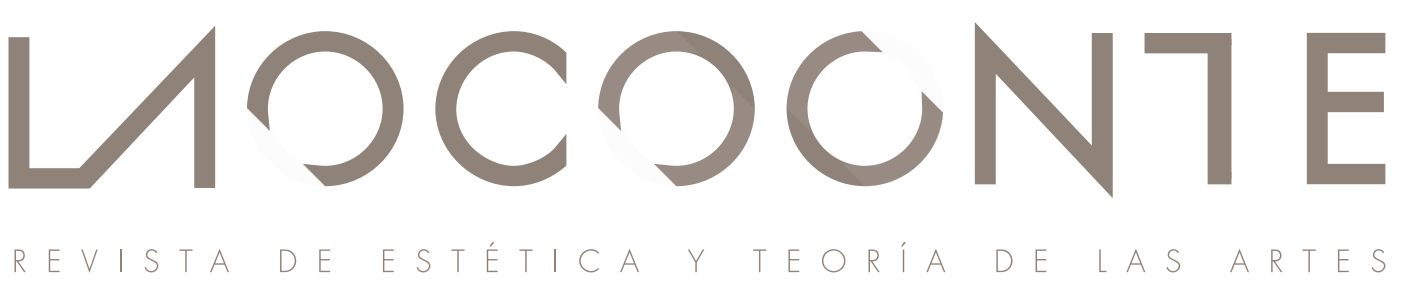

$\mathrm{N}^{\circ} 6 \cdot 2019$

PRESENTACIÓN

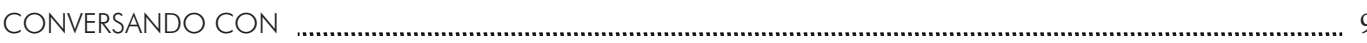

"El producto del diseñador es un proyecto, el estado previo de un objeto", Entrevista con Norberto Chaves,

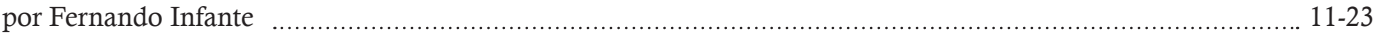

El papel de la investigación y la teoría en diseño. Una conversación abierta, por Fernando Infante

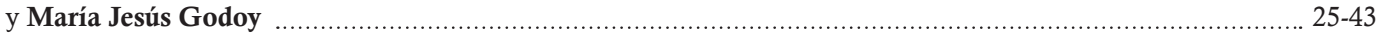

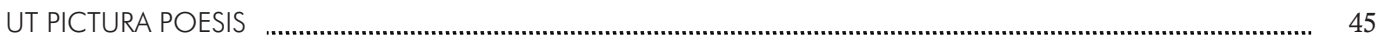

Abandonar la escritura. Poesía experimental y manifiesta, Ignacio Gómez de Liaño ................................................ 47-95

Imágenes de Laocoonte n. 6, de Isadora Gonzaga ................................................................................................... 96-97

PANORAMA

FILOSOFÍA DEL DISEÑO

Pensar el diseño, Fernando Infante y María Jesús Godoy (Coordinadores) .............................................. 101-105

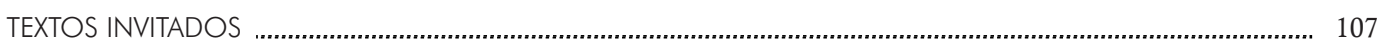

Estatus y estado del diseño más allá del objeto, Pedro Medina Reinón . ................................................... 109-125

Mar de Nubes. Cuerpo de Cristal, Dionisio González .............................................................................. 127-133

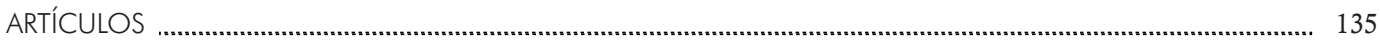

Understanding Design Aesthetics beyond Functional Beauty accounts, Lucía Jiménez Sánchez ................. 137-149

Estética y diseño industrial: debates y controversias, Joan M. Marín _...................................................... 150-164

Del ornamento al delito. El diseño y la sociedad en Charles Baudelaire y Adolf Loos, Jorge López Lloret ... $165-182$

When is Architecture not Design? Saul Fisher ……............................................................................. 183-198

Diseño y habitabilidad: una aproximación basada en los lenguajes de patrones, Antonio Hidalgo Pérez ...... 199-215

Marcel Breuer: un diseñador global. Experiencias en el ámbito de la vivienda prefabricada,

Salvador José Sanchis, Ignacio Peris y Pedro Ponce

Diseño y artes escénicas: el papel de Oskar Schlemmer en Das Triadische Ballett y la actualidad de la Bauhaus, Milagros García Vázquez

Lo performativo en prácticas de arte y diseño actuales vinculadas a procesos de innovación social.

El caso de La Venezia che non si vede y de La borda, Tània Costa Gomez

Articulaciones de la estética y el diseño. El caso de la evaluación a partir de la investigación dirigida en la carrera de diseño escénico de la Universidad de las Artes de Cuba, Mara Rodríguez Venegas

y Xiomara Romero Rojas

SUPLEMENTO 
Walter Gropius. La vida del fundador de la Bauhaus, Jorge Martínez Alcaide

¿Qué significa pensar la política desde la estética? Àger Pérez Casanovas

Ideologías estéticas en los orígenes de la pintura moderna, José Luis Plaza Chillón 300-303

Sobre a estética, Luis Carlos Pereira

Músicas populares. Sociedad y territorio: Sinergias entre investigación y docencia, Mar Aleixandre Badenes.

307-309

La necesidad de la mirada antropológica sobre la literatura, Pablo de Benito David

A propósito de Chandler, o la novela policíaca como tratado filosófico, Juan Evaristo Valls Boix

Videre aude!, Anacleto Ferrer

La inaplazable memoria del dolor y el sufrimiento, Antonio Notario Ruiz

La alargada sombra de la pintura, Raquel Baixauli

Sondear la maravilla, Juan Evaristo Valls Boix

... Y lo sabes, Marc Hernández Montoro

Arqueologías de la modernidad en las artes. Ensayo estético, Carlota Fernández-Jáuregui Rojas

Estética de la Instalación, Luis Cemillán Casis

La Herencia de otra época, María Jesús Godoy Domínguez

Del Theatrum Mundi al Gran Vidrio, Miguel Salmerón Infante

Imágenes de Isadora Gonzaga.

Fotografía de portada de Tamara Djermanovic intervenida por Isadora Gonzaga.

Los coordinadores de la sección Panorama: Filosofia del diseño agradecen

a Antonio Molina Flores su colaboración. 
ner.

llobj vidada, o de ma la publica. los de la im nalidades po ndientn $\mathrm{A}$ -
, la

que e.

usdño, si nn

ज. " da yara el mu tual y d

or enc or las orígenes un tmo, fía del diseño,

rpintero que'curra la forma de

eña Desige para un mundo complexo, de los bienes producidos por el hombre :tores subjetivos también influyen en su

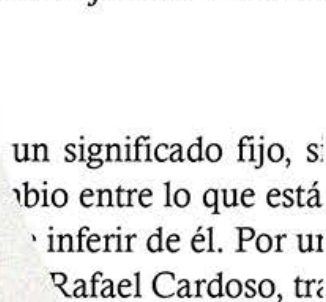

Rafael Cardoso, tri

No hay cómo no e método, de pensa 1, donde la reación en geperal. salizar la forma pa. rue amb ${ }_{\text {Snceptual por }}{ }^{1}$

$$
\text { -rola ol } n^{\prime}
$$

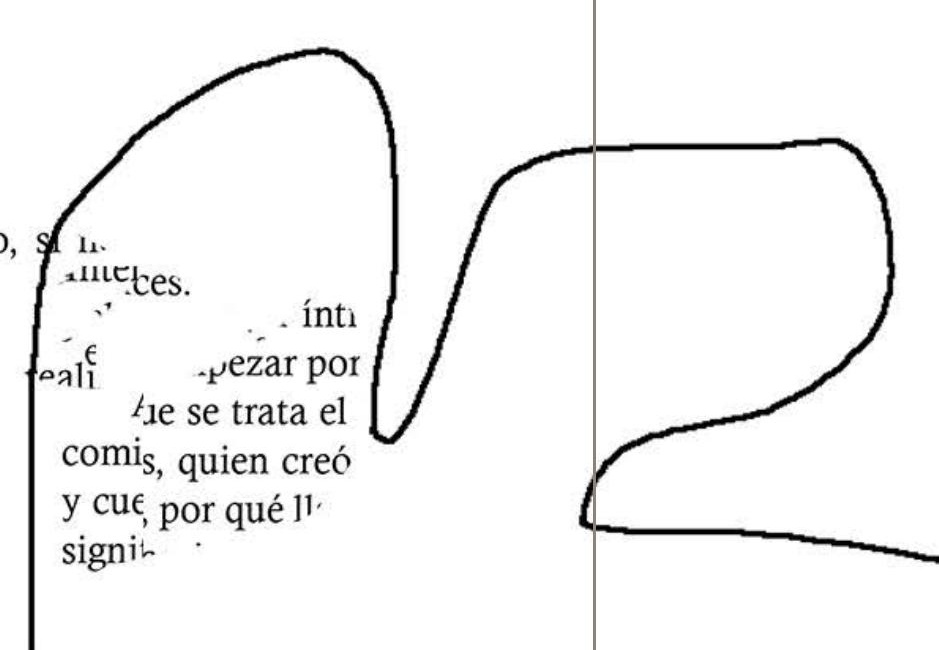

LOCOCNTE

PANORAMA: FILOSOFÍA DEL DISEÑO

Fernando Infante del Rosal y María Jesús Godoy Domínguez

(Coordinadores) 
No hay cómo no hablar de una filosofía del diseño, si no de izar la forma para el mundo sensible. Tción de formas y de la

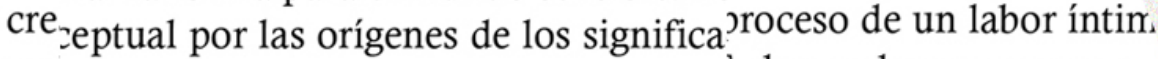

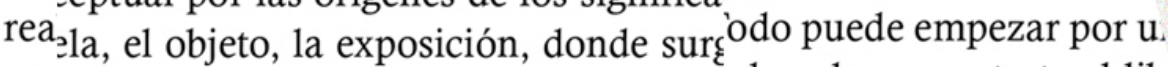

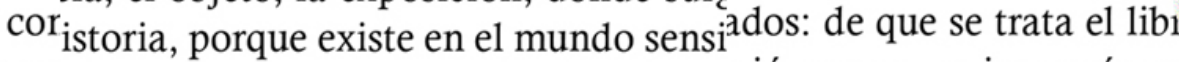
noładas sus raíces. Desde allí cojo el hilo gió, que es, quien creó y p su len conceptual y donde el está ubicado.ible o aún, por qué llama as

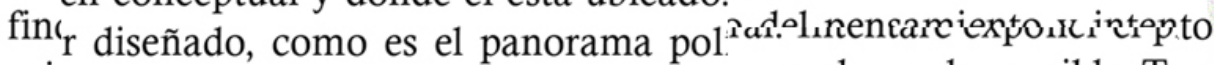
ori $_{\text {evolando la inmanencia del concepto. }}$ para el mundo sensible. Tc ce a s a forma al objeto y el diseñad ${ }^{\text {as }}$ orígenes de los significa)olo sob lengua olvidada, o como un cr la exposición, donde surg̨ido - nrocesr a un trozn de madera amnrfo le existe en el mundo sensin trai lengua olvidada,adas sus raíces. Desde allí cojo el hilona de ablo de procesc a un trozo de men conceptual y donde el está ubicado. perspectiva de lidoso en la publr diseñado, como es el panorama polndo ho, un camino diar ejemplos de levolando la inmanencia del concepto.: por una investigacióus funcionalidadı a forma al objeto y el diseñadı infl ro, el cuento, luso, dependiendı lengua olvidada, o como un $\mathrm{C} i^{\prime}$

qué, cuál e s nrecese a un trozo de madera amorfo

ata el 1

،en creó y pu.

or qué llama así, d

miento y intento a lles
- puede inferir de él. Por un in -reación ". (Rafael Cardoso, trad. 26 el ambiente que cerca el ol, especie de un danza en que ambos eleme iles son los símbolos que estso.

lmente, el contenido contextrño y hacer diseño, es antes de todo cue rna el papel de un tra o que toma la forma $\mathrm{d}^{\text {g }}$ gradual, donde la idea $\mathrm{do}_{\text {, las ideas, los relacioname }}$ danza en que ambos ropio proceso y también de r

'esign para un mundo liseñar, me planteé la cuesti' s bienes producidos por seño, es antes de tod prima eso me dá? Ejemp' es subjetivos también inf ble. Diseñar puede se ese texto, construyo el d

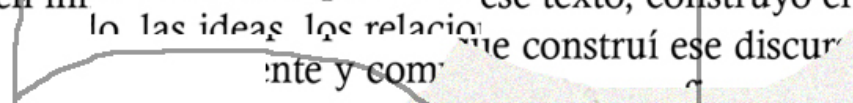

1 un significado fijo, sino que expresajue ${ }^{\dagger}$ mbio entre lo que está incrustado en Sre ¿de inferir de él. Por un lado, las form ". (Rafael Cardoso, trad. 2014)

rradual, donde la i’ 
- ormas y de rapo.

eso de un labor íntimo, un udo puede empezar por una inves 'dos: de que se trata el libro, el cu jió, que es, quien creó y por qué, ble o aún, por qué llama así, donı del pensamiento y intento a lle: Cual es el ambiente que cerca e ico. cuáles son los símholos aı

de una filosofía del diseño, si r e construcción de formas y de exponer el proceso de un labor í o sensible. Todo puede empezar los significados: de que se trata h, donde surgió, que es, quien creó y po mundo sensible o aún, por qué llama as cojo el hilo del pensamiento y intentc está ubicado. Cual es el ambiente que $\mathrm{g}$ anorama político, cuáles son los símb el concepto. Gradualmente, el conten y el diseñador encarna el papel de ur como un carpintero que toma la forr
LAU1 L11 glilla1. 111 n un sigizar la forma para e] ede inferifeptual por las orígt “. (Rafabla, el objeto, la exp istoria, porque exist y gradua adas sus raíces. De: en conceptual y do sible. $D$ : $r$ diseñado, como do, las icevolando la inman propio pri diseñar, a forma al prima e lengua olvi ese textos nrncesr a un trnzo ue construí ese discurso, he hecho de ara un reconfiguración de significado en para ilustrar... (en construccion) antiguas formas, es lanzar al mundo 1. La responsabilidad aquí se hace tamos elaborando, significados para

am mundo complexo. São Paulo,

1 agosto). Significado. Recuperado 1 br/significado/

\section{ИつCつCN7E}

PANORAMA: FILOSOFÍA DEL DISEÑO ARTÍCULOS 
- ormas y de rapon

aso de un labor íntimo, un udo puede empezar por una inves 'dos: de que se trata el libro, el cu rió, que es, quien creó y por qué, ble o aún, por qué llama así, donı del pensamiento $\mathrm{y}$ intento a lle Cual es el ambiente que cerca e ticn. cuáles son los símbolos a

de una filosofía del diseño, si r e construcción de formas y d $\epsilon$ exponer el proceso de un labor í o sensible. Todo puede empezar. los significados: de que se trata 1, donde surgió, que es, quien creó y po mundo sensible o aún, por qué llama as cojo el hilo del pensamiento y intento está ubicado. Cual es el ambiente que $q$ anorama político, cuáles son los símb lel concepto. Gradualmente, el conten y el diseñador encarna el papel de u somo un carpintero que toma la forr

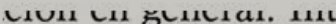
un signizar la forma para e] ambio eni ede inferieptual por las oríge n ". (Rafaəla, el objeto, la exp y gradua istoria, porque exist n danza adas sus raíces. De: en conceptual y do] sible. Dis $r$ diseñado, como do, las icevolando la inmanı ropio pri diseñar, $r$ ¥ forma al prima e lengua olvi

ese textos nrncesr a un trnzo ue construí ese discurso, he hecho de ara un reconfiguración de significado en para ilustrar... (en construccion) antiguas formas, es lanzar al mundo 1. La responsabilidad aquí se hace stamos elaborando, significados para

um mundo complexo. São Paulo,

1 agosto). Significado. Recuperado 1 $\mathrm{br} /$ significado/ 


\title{
Diseño y artes escénicas: el papel de Oskar Schlemmer en Das Triadische Ballett y la actualidad de la Bauhaus
}

\section{Design and performing arts: the role of Oskar Schlemmer in Das Triadische Ballett and the present of the Bauhaus}

\author{
Milagros García Vázquez
}

\begin{abstract}
Resumen
Existe una obra estrechamente vinculada al universo de la Bauhaus, Das Triadische Ballett, ballet creado en gran parte por Oskar Schlemmer, cuyo diseño, desde el escenario, el vestuario, la coreografía, e incluso la música, comenzó sin embargo a nacer antes de la aparición de la institución fundada por Walter Gropius. Cuál fue su génesis, cuál fue el papel del diseño en el proceso creativo que le dio forma, hasta qué punto llegó la implicación de Schlemmer en esta obra y cómo ha pasado a estar su nombre tan íntimamente unido a la Bauhaus, son algunos de los objetivos de este estudio. Asimismo, es esta puesta en escena una ocasión constante para ver actualizados los parámetros en los que se movería la escuela artística alemana, pues se trata de una obra de la que aún hoy, desde que la idea surgiera en 1912, pueden seguir viéndose representaciones.
\end{abstract}

Palabras clave: Bauhaus, Oskar Schlemmer,

Triadisches Ballett, diseño, escena, danza.

\begin{abstract}
There is a work closely linked to the universe of the Bauhaus, Das Triadische Ballett, a ballet created largely by Oskar Schlemmer, whose design, of the stage, costumes, choreography, and even the music, began nevertheless before the appearance of the institution, which was founded by Walter Gropius. What was its genesis, what was the role of design in the creative process that shaped it, how extent was the Schlemmer's involvement in it and because is its name so intimately joined to the Bauhaus, are some of the goals of this article. Also, this play is a constant opportunity to update the parameters of this artistic German School, because this work, since the idea was born in 1912, can still be seen performed even today.
\end{abstract}

Keywords: Bauhaus, Oskar Schlemmer, Triadisches Ballett, design, stage, dance.

\section{La actualidad de la Bauhaus a escena}

"En la pintura de Oskar Schlemmer vive una nueva energía espacial... Despierta en el espíritu del espectador la idea de una cultura venidera de la totalidad, una cultura donde todas las artes serán reunidas de nuevo" (Maur 1977: 9). ${ }^{1}$ Estas palabras, dirigidas por Walter Gropius en 1961 a la memoria del ya por entonces desaparecido Oskar

1 Texto original en alemán, traducción propia. Todas las citas extraídas de originales en alemán, inglés o francés, son traducciones propias.

* Universidad Pontificia de Comillas, España.mgvazquez@comillas.edu Artículo recibido: 31 de mayo de 2019; aceptado: 15 de octubre de 2019 
Schlemmer, podrían ser aplicadas a la propia actividad de la Bauhaus, donde el polifacético artista trabajaría desde 1921 hasta 1929. Esa "cultura venidera de la totalidad" es la fomentada desde las filas del profesorado de los Bauhäusler, tanto por el propio Gropius, cabeza y fundador, como por J. Itten, W. Kandinsky, L. Feininger, L. Moholy-Nagy, J. Albers, G. Stölzl, P. Klee, M. Breuer o H. Bayer, algunos de los docentes más destacados. Junto a la arquitectura, la pintura, la escultura, el diseño de tejidos, el dibujo, la fotografía, en el marco de la riqueza creativa de la Bauhaus estarán también presentes las artes escénicas -en las que Schlemmer tendrá un papel fundamental-, y todo lo que ellas comportan, es decir, espacio, movimiento, luz, color, música, temporalidad, y también diseño, el de los decorados y el del vestuario de los diferentes personajes. La especificidad de estas artes del escenario otorgan a sus creaciones una nota distintiva importante, la de un inmanente potencial de actualización, pues, una vez diseñado el decorado, elaborado el argumento y dispuestos los demás componentes, las obras pueden volver a representarse una y otra vez, bien en su versión original, o bien con las variantes aportadas por los diferentes directores que las pongan de nuevo en marcha. Por esta razón, toda recuperación hecha hoy de los trabajos realizados en este ámbito dentro de la Bauhaus, es una notable forma de actualización de este espacio creativo que ve cumplirse en 2019 sus cien años de historia. El análisis de esta potencial actualidad es el objeto de las páginas siguientes.

Una de las representaciones escénicas más innovadoras de los primeras décadas del siglo XX, y donde el diseño resulta un elemento esencial es, sin duda, Das Triadische Ballett (El Ballet Triádico). Un proyecto estrechamente vinculado tanto a Schlemmer, como a la Bauhaus. Al primero, por ser creador y artífice, y a la segunda, por haber obtenido dentro de ella el primer gran éxito ante el público. Bien es cierto que la gestación de la obra precede a la fundación de la escuela, lo mismo que su primera puesta en escena en 1922, pero en su diseño, contenido artístico y estético, y en su progresiva constitución, sus parámetros son equivalentes a los de la que sería catalizadora de las nuevas energías artísticas emergentes a principios de siglo en el centro de Europa, la propia Bauhaus.

Ante estas afirmaciones se podrían abrir dos cuestiones, cómo nace la vocación de Oskar Schlemmer por el mundo de la escena, y cuál fue el proceso completo por el cual Das Triadische Ballett está hoy tan estrechamente unido al mundo de la Bauhaus, a pesar de haber sido creado fuera de ella, que su estudio se ha convertido en una de las vías de acceso para mejor conocimiento de los presupuestos y directrices de los que parte y en los que incide el trabajo realizado en el seno de esta institución artística.

\section{Oskar Schlemmer y su vocación artística}

Comencemos por la trayectoria de Schlemmer. Ésta ofrece, por un lado, una panorámica condensada de las nuevas corrientes de principios del siglo XX; y por otro, justifica la integración del artista en el universo, podríamos decir, "pluriartístico" de la Bauhaus. Del mismo modo, su evolución da cuenta de cuál fue su contribución a ella, así como de su denodado interés e intensa dedicación en el Ballet Triádico. Desde niño se relaciona con las artes, su abuelo paterno, pastelero, era conocido por las artísticas imágenes y dibujos con los que adornaba sus dulces, su padre obtuvo algunos reconocimientos como comediógrafo, y su abuelo materno era orfebre. El joven Oskar destaca en las clases de arte impartidas en la escuela, obteniendo algún galardón, pero pronto ha de salir para aprender un oficio tras la muerte de su padre y la subsiguiente 
necesidad económica. Aun así, su formación profesional sigue incardinada en el mundo del arte, consiguiendo su título de artesano en dibujo para marquetería, enseñanza donde conoce todo el proceso, desde el dibujo al patronaje, el traslado del modelo, el recortado de las piezas y su montaje. Su primer trabajo se enmarcará dentro del Jugendstil, colaborando en la realización del panel El hermanamiento de Europa y América diseñado por Hans Christiansen para la Exposición Universal de St. Louis en 1904.

En 1906 obtiene una beca para estudiar en la Academia de Bellas Artes de Stuttgart, perfeccionando su talento natural para el dibujo, la pintura y la composición. Conoce a los que serían sus más cercanos amigos, al pintor y diseñador gráfico suizo Otto Meyer-Amden y a Willi Baumeister, también pintor y diseñador gráfico, además de escenógrafo, fotógrafo y tipógrafo. Con el primero realizaría su primera pintura mural, una Anunciación ${ }^{2}$ para la capilla católica de la "Ausstellung Kirchlicher Kunst Schwabens" ("Exposición de Arte Sacro de Suabia") en Stuttgart.

En 1911, durante un viaje a Berlín, se aproximará al mundo de las Vanguardias artísticas, entrando en contacto con el círculo de artistas vinculados a la revista expresionista Der Sturm, editada por el escritor, galerista y músico Herwarth Walden. Aquí conocerá además el Cubismo, mostrando especial aprecio hacia la obra de Picasso y Derain en unas primeras tentativas. A su regreso a Stuttgart en 1912, comienza su carrera como profesor en la Academia de Bellas Artes, abriendo al año siguiente una sala de exposiciones junto con su hermano Willy, el "Neuen Kunstsalon am Neckartor", donde podrán verse por primera vez en la ciudad obras de artistas de Vanguardia como Kandinsky, Klee, G. Münter, F. Marc, O, Kokoschka, Meyer-Amden, G. Braque, A. Gleizes, o J. Metzinger. La galería se ve obligada, sin embargo, a cerrar al año siguiente, debido a las duras críticas recibidas por parte de la prensa.

Su participación en la "Werkbund-Ausstellung" de Colonia en 1914, con algunos de los paneles ${ }^{3}$ destinados al pabellón principal construido por Theodor Fischer, le permitirá conocer a Ernst Ludwig Kirchner y muy probablemente será entonces cuando tenga un primer contacto con Gropius. El viaje que inicia después del evento le lleva a Londres, Amsterdam y París, hasta que con la irrupción de la Guerra es destinado a la infantería del frente occidental. Herido al año siguiente en un brazo, sigue pintando durante su convalecencia hasta su recuperación y nuevo destino en el cuartel de Gaisburg.

En las vacaciones de 1916, concedidas durante la guerra a los estudiantes, experimenta con diversas composiciones abstractas, como en Bild $K$ (Landesmuseum Münster, Depositum Schlemmer) o Komposition auf Rosa (Landesmuseum Münster, Depositum Schlemmer). En la primera, los motivos gráficos reducidos a líneas y pequeñas áreas de color grises, blancas y negras, recuerdan el mundo en que vive en esos momentos, hélices y alas de avión, un visor de tiro y, junto a ellos, la palabra Bild y la letra K. Maur (1977) ha relacionado esta letra con el siguiente contenido de una de las páginas de su diario, ${ }^{4}$ vinculándola a la palabra "Kampf", ("lucha") al evocar esta imagen la visión de un piloto ante su campo de actuación. ${ }^{5}$

\footnotetext{
2 No conservada.

3 No conservados.

$4 \quad$ Fechadas a mediados de marzo de 1916.

5 Volker Demuth vincula esta letra a las palabras "Kunst" y "Krieg", "arte" y "guerra" respectivamente en alemán (Demuth 2002: 189).
} 
¿Cómo es posible alcanzar la profundidad en el arte? ¿Cómo oponer resistencia a los impedimentos consustanciales a la habilidad? ¿Cuál de estos impedimentos es el más fuerte? ¿Cómo transformar la idea en una forma? ¿Cómo trasladar nuevas ideas a nuevas formas? Emprendo una lucha contra mi línea renacentista. ¿El campo de batalla? Austeridad, forma, superficie. Las formas de lo nuevo. Sin técnica, sin trucos artísticos. Sólo fijando lo necesario (Schlemmer 1989: 24-25). ${ }^{6}$

En Komposition auf Rosa aparece la figura humana, plana y geométrica, elaborada a partir de líneas rectas, formas circulares y superficies lisas de color sin matices. Una esencial simplicidad en la línea de uno de sus artistas más admirados, y quizá modelo para sus aspiraciones, Klee. Al final de este verano, Schlemmer escribe en su diario:

Klee es el espíritu moderno conocido más cabal. [...] El trabajo de Klee es absolutamente maravilloso. Con una línea mínima es capaz de desvelar toda su verdad. [...] Ella lo es todo, íntima, delicada, es todo lo mejor, y es, sobre todo, nueva. [...] Las obras de todos los hombres importantes tienen sus raíces en un conocimiento simple aunque ampliamente abarcante. Este hallazgo supone haberse encontrado a sí mismo, y con ello, el mundo y todas las cosas (Schlemmer 1989: 28-29). ${ }^{7}$

Al terminar la contienda, hecho que vive destinado en Berlín, regresa a su Stuttgart natal donde sigue trabajando en la Academia de Bellas Artes. Junto con otros compañeros $^{8}$ forma parte del "Üecht Gruppe", abogando por un cambio en el sistema formativo de la Academia y apoyando la venida de Klee como sustituto del anterior director, Adolf Hölzel. Gropius respaldaba la iniciativa. Para refrendar sus propósitos organizan una exposición, "Herbstschau Neuer Kunst", con sus propias obras, con algunas de las más conocidas realizadas por los artistas del grupo berlinés "Sturm" y dedicando una sala especial a Klee, invitando así al debate sobre su obra. Schlemmer expone aquí, entre otras, Plan mit Figuren (Staatgalerie Stuttgart), un lienzo donde predomina una estricta geometría y el suave modelado de los cuerpos. Semejantes a figurines de madera, tienen el aspecto de ser patrones modulares para otras obras, o ensayos para figuras terminadas, a modo de tentativas en proporciones, medidas y relaciones entre sí, con áreas de color, unas veces planas y otras tonales para dar sensación de corporeidad. Todo un juego de volúmenes que anuncia las figuras plásticas y densas que compondrán sus futuras pinturas. La exposición obtuvo un eco positivo y considerable, aunque el objetivo no se logró y Arno Waldschmidt fue elegido director en lugar de Klee.

En 1920 Schlemmer abandona la Academia, colabora con el grupo "Sturm", y sigue exponiendo sus obras, ahora en la Galerie Arnold de Dresde, junto a los trabajos de Baumeister y Kurt Schwitters. Gropius le pide entonces formar parte del profesorado de la Bauhaus, ubicada entonces en su primera sede, Weimar. Se encarga allí primeramente de los talleres de escultura en piedra, pintura mural -junto con Itten- y dibujo anatómico. En este mismo año el escritor, dramaturgo y pintor Lothar Schreyer

6 Afirma después cómo la fotografía y el cine posibilitaron un arte propio de un mundo nuevo, el arte abstracto, que "hace aquello que la fotografía no puede hacer". Aunque, precisamente en la Bauhaus, esta línea generatriz del arte moderno desde el Impresionismo, será superada gracias a los experimentos fotográficos de MoholyNagy.

$7 \quad$ Septiembre de 1916

8 Gottfried Graf, Albert Kinzinger, Albert Müller y Hans Spiegel. 
es convocado para abrir una nueva área de creación en la Bauhaus, el taller de escenografía, una iniciativa cuyo conocimiento acoge Schlemmer con gran entusiasmo, enseguida conoceremos los motivos.

Se percibe ya en aquel momento el enfrentamiento entre las diferentes posiciones de Gropius e Itten. Unas divergencias recogidas por Schlemmer en sus cartas a Meyer-Amden ${ }^{9}$ de 1922. Por un lado, la mentalidad práctica de Gropius; por el otro, el carácter místico de Itten; uno piensa en el trabajo eficaz mediado por la técnica, y el otro, en el desarrollo de las capacidades creativas de los alumnos en condiciones de silencio y mediante experiencias interiores concretas. Itten confiesa a Schlemmer su deseo de marcharse, ante lo cual Gropius prepara la venida de un nuevo profesor, Kandinsky, que se incorporará en este mismo año. Es ahora cuando las siluetas vistas en algunas de las mencionadas obras de Schlemmer encuentran su expresión acabada en Die Geste (Tanzerin, Bayerische Staatsgemäldesammlungen, Neue Pinakothek München). Imagen elocuente de su inclinación hacia el mundo de la escena, de hecho, confiesa a Meyer-Amden que cada vez son más quienes le dicen que el teatro es lo suyo (Schlemmer 1989: 82). ${ }^{10}$ En un cuadro de dos metros por uno, una inmensa figura parece haber terminado su paso de baile y estar en suspensión esperando el aplauso, estirando brazos y piernas, rodeada por un resplandor al fondo como un eco de sus propias formas.

Cuando en 1923 llega a la escuela Moholy-Nagy, la convergencia entre arte y técnica impregna la orientación pedagógica y creativa de las diferentes áreas. La fotografía y las grabaciones fílmicas adquieren un progresivo protagonismo en detrimento de la pintura. Schreyer abandona la Bauhaus en estos meses, y Schlemmer queda sólo, al frente del área dedicada a las artes escénicas.

Cuando el poder político cambia de orientación en Turingia, y gobiernan los opositores del estilo de la Bauhaus, los integrantes de la escuela se plantean el traslado, eligiendo Dessau como nuevo destino. Poco a poco la institución se transforma, y lo que era un centro para la educación y fomento de la creatividad artística, se va tornando en una empresa de producción casi industrial. Comienzan a surgir grupos que presionan para realizar una reforma en el funcionamiento interno, Gropius se ve obligado a dimitir. Le sustituye el suizo Hannes Meyer, quien pondrá el foco de atención en impulsar el trabajo y rendimiento de los talleres y en activar el departamento dedicado a la arquitectura. La función de la Bauhaus es ahora esencialmente social, más que artística, tal como declara el propio Meyer en un texto que podría considerarse su manifiesto:

Construir y crear son lo mismo, un acontecimiento social. [...] La Bauhaus de Dessau no es un fenómeno artístico, sino social. Como organismo creador, nuestra actividad está condicionada socialmente. [...] Nuestro trabajo es la búsqueda de la forma armónica esencial. No buscamos un estilo Bauhaus, ni una moda Bauhaus, ni superficies ornamentales a la moda divididas en líneas horizontales y verticales, inspiradas por el Neoplasticismo, ni imágenes geométricas o estereométricas sin vida y contrarias a la funcionalidad. [...] El objetivo final del trabajo de la Bauhaus es reunir todas las fuerzas vitales para la constitución armónica de nuestra sociedad (Meyer 1929: 2). ${ }^{11}$

9 La correspondencia mantenida entre ambos, como veremos en este estudio, es una de las fuentes más ricas a la hora de estudiar la obra y profundizar en el pensamiento estético de Schlemmer.

10 Carta a Otto Meyer-Amden, fechada en Weimar, el 13 de marzo de 1922.

11 La revista Bauhaus. Zeitschrift für Gestaltung comienza a editarse tras el traslado desde Weimar a Dessau, aparecerá 
Moholy-Nagy, Breuer y Bayer dejan la Bauhaus en 1928, Schlemmer lo hará en 1929 para comenzar una nueva etapa en la Academia de Artes y Oficios de Breslau. ${ }^{12}$

\section{E1 origen de Das Triadische Ballett}

La iniciativa de contar en la Bauhaus con un área dedicada a la escenografía es acogida, decíamos, con gran alegría por parte de Schlemmer, y es que prácticamente había consagrado su vida al mundo de los escenarios ya desde el año 1912. En aquellos momentos, cuando acababa de regresar a Stuttgart, ésta se había convertido en un centro vivo para el arte moderno, punto de encuentro no sólo para sus amigos Baumeister y Meyer-Amden, sino también para el pintor H. Stenner, los arquitectos G. Schleicher -más tarde colaborador de Adolf Loos-, R. Herre o R. Döcker, creadores pertenecientes al círculo de Hölzer. En este ambiente se movería el primer bailarín del Ballet Real de Stuttgart, Albert Burger y su esposa Elsa Hötzel. Baumeister hará las presentaciones entre Schlemmer y los Burger, iniciándose una estrecha amistad, que les llevaría a idear juntos el Ballet Triádico.

El matrimonio había pasado ese verano unos días en Hellerau, barrio al norte de Dresde, toda una referencia para el arte escénico moderno gracias a la escuela rítmico-musical abierta allí por Emile Jacques-Dalcroze ${ }^{13}$ en 1911. Todos aquellos que deseaban estar al día de las últimas novedades en música y danza acudían a la escuela o a sus actividades.

Un importante colaborador de Dalcroze fue el escenógrafo Adolphe Appia, quien encontró aquí un lugar donde la importancia concedida a las relaciones entre el cuerpo, el espacio escénico y la música, le permitirían poner en práctica sus novedosas ideas sobre la puesta en escena. Planteamientos que tenían en cuenta la integración entre dichos tres elementos y sus condiciones temporales y dinámicas, junto con los juegos de luces, sombras y colores.

Appia había conocido la didáctica de Dalcroze ya en Génova en 1906, escribiendo poco después:

Mis impresiones fueron complejas y sorprendentes, en un primer momento me sentí conmovido hasta las lágrimas, recordando durante cuánto tiempo lo había estado esperando. Pero pronto sentí el despertar de una nueva fuerza completamente desconocida para mí. Ya no me encontraba entre el público, estaba en el escenario junto con los actores (Appia 1924: 383). ${ }^{14}$

A partir de aquí, le queda claro el modo de encaminar sus inquietudes sobre la expresión musical del cuerpo y sus posibilidades relacionales con el entorno y, por

periódicamente desde 1926 hasta 1931.

12 Se aproximaba la disolución de la Bauhaus. En 1930 Meyer es sustituido por Mies van der Rohe, continuador de la línea iniciada por su predecesor cada vez más orientada hacia la arquitectura. Tras la derrota socialdemócrata en Dessau en las elecciones de 1932, la Bauhaus se traslada a Berlín. Cuando los nacionalsocialistas 1legan al poder en 1933, el gobierno cierra sus puertas.

13 Dalcroze desarrolló un método musical (eurítmica) cuya pedagogía contempla la relación entre música, movimiento y coordinación, combinando el solfeo con la expresión corporal rítmica y su relación con el espacio y la improvisación. "La educación por y para el ritmo es capaz de despertar el sentido artístico de todos los que se sometan a ella" (Dalcroze 1920: 115).

14 Citado en Beachman 1985: 155. Las principales teorías escenográficas de Appia pueden encontrarse en su libro Musik und die Inszinierung (1899). 
ende, con el espectador: "El método me fue revelado por Dalcroze en 1906, sin cambiar mi orientación, su eurítmica me liberó de una tradición demasiado inflexible, y, particularmente, del decorativismo romántico de Wagner. [...] La eurítmica determinó mi evolución futura" (Appia 1924: 378). ${ }^{15} \mathrm{El}$ sistema lo resume el propio Appia en una carta dirigida al mismo Dalcroze: "La externalización de la música (es decir, su rehabilitación) es una idea que he estado deseando durante muchos años. Nada puede salvar a la música de su suntuosa decadencia excepto la externalización" (Beachman 1994: 74).

Esta experiencia vivida por Appia, será compartida por Burger cuando conoce el mundo creado en torno a las ideas de Dalcroze en Hellerau. Esa misma posibilidad abierta de expresión, mediante el dinamismo del cuerpo humano, comprendido en su libertad de movimientos, involucrado con el color y las formas plásticas, desplegando sus gestos al son de una pieza musical desarrollada en el tiempo y en el espacio del escenario, no sólo entusiasma Burger, sino que se correspondería con las inquietudes expresivas de propio Schlemmer. Muestra de ello será cómo ambos trabajan dichas cuestiones y sus soluciones durante la gestación y proceso creativo del Ballet Triádico.

Burger se siente igualmente liberado al encontrar este nuevo ámbito de acción, tan parejo a su deseo de romper con el mundo del ballet clásico en el que había sido formado y al que había dedicado su carrera. Al regresar a Stuttgart, comienza ya a planear un proyecto con una puesta en escena nueva, revolucionaria. Paralelamente, la ciudad cuenta ya con iniciativas, en principio, propiciatorias, para ver nacer otra propuesta audaz y novedosa. Nos referimos a las actuaciones de la bailarina letona Sent M'ahesa, o a las de la alemana Clotilde von Derp. Representantes señeras de la "Danza expresionista" (Ausdruckstanz) de la que fueran pioneras Isadora Duncan o Loïe Fuller. Su peculiar forma de moverse en el escenario rompía con las reglas clásicas del ballet, al proponer como alternativa la expresión individual, creativa, espontánea del cuerpo en movimiento, haciendo partícipes de él al color, los tejidos y las luces. Igualmente, se habían visto allí las especiales puestas en escena de Rita Sacchetto, quien dotaba movimiento con su danza a diferentes pinturas y obras de arte. Eran las llamadas Tanzbildern. Ejecutadas como ecos de los Tableau Vivant del siglo XIX, se diferencian de ellos por el hecho de no ser el principal objetivo reproducir e manera estática una pintura, ${ }^{16}$ sustituyendo a las figuras por personas, sino el emplear la obra para, combinando artes visuales, movimiento y música, crear representaciones dinámicas de esas obras. Su propósito era el de expresar, de forma personal, todo lo que el artista utilizando únicamente la pintura, el plano en dos dimensiones, no pudo mostrar. La misma intención ponía en sus representaciones coreográficas de los poemas Ibsen o Whitman, aspirando a dar forma y vida en el escenario a las palabras escritas sobre el papel.

Es importante tener en cuenta este ambiente creado en torno al mundo de la danza a principios del siglo XX, pues aquí surgirán, se alimentarán y desarrollarán las ideas de Schlemmer, sobre escenografía y movimiento en particular, y sobre el arte en general. Como se desprende de estas experiencias del ballet moderno, las novedades provienen en su mayor parte de la interacción de esta disciplina artística, la danza, con las artes plásticas, en definitiva con el diseño de formas, y la aplicación, cargada de

15 Citado en Beachman 1985: 155.

16 Saccheto tomaba como referencia obras de los pintores Thomas Gainsborough, Joshua Reynolds, Sandro Botticelli o incluso Velázquez (véase Simonson 2013). 
significado, de los colores en esos mismos diseños, cuyo uso supera ahora una función meramente decorativa. Formas a las que se suman el diálogo entre ellas, el conjunto de sus movimientos, la música que los anima, las variaciones de luces y sombras y su contextualización espacial en el escenario.

No hay que olvidar en este punto, por otra parte, el papel jugado al respecto por las novedades musicales. En estos años, la segunda década del siglo XX, la población de la ciudad de Stuttgart tuvo la ocasión de poder escuchar el Pierrot Lunaire de A. Schönberg, concretamente el 11 de noviembre de 1912, bajo la dirección de Hermann Scherchen. La obra original es un conjunto de cincuenta poemas en forma de rondel publicados por el belga Albert Guiraud en 1884. En ellos se cuenta la historia de algunos de los personajes de la Commedia dell'Arte, Colombina, Arlequín, el viejo Doctor y el sol del ocaso y la luna. Otto Erich Hartleben traduce los poemas al alemán en 1893, trasladando a los personajes a un contexto moderno, y sin conservar las rimas y longitud originales de los versos. La cantante Albertine Zehme pide a Schönberg escribir la música para cantar ella misma una selección de dichos poemas. El músico suma al ritmo sincopado de la versión de Hartleben la ruptura del relato al dividir la selección de los poemas en episodios melodramáticos breves y al utilizar la atonalidad en la composición. La prensa local describe la incomprensión del auditorio ante la obra por parte, y es que gran parte del público se marchó de la sala antes del final. Sin embargo, algunos espectadores se sintieron verdaderamente entusiasmados ante la nueva música, entre ellos los mismos Schlemmer y Burger. El bailarín creyó encontrar en el compositor austríaco a la persona ideal para crear el acompañamiento musical más apropiado a su ballet, sobre todo por las analogías reconocidas con la pieza de Schönberg en la historia, los personajes, y la búsqueda de la novedad en el ritmo y desarrollo. Burger escribe una carta al músico, explicándole la naturaleza del proyecto.

Como bailarín principal del Teatro Real me dedico de forma independiente a la danza moderna, apoyándome principalmente en las ideas de Dalcroze. Busco mostrar la novedad de mis pensamientos en forma de pantomima. Aspiro a encontrar una unidad entre danza, escenario y música, y trabajo con algunos pintores en el diseño de la escena y del vestuario. Su música, que acabo de conocer en el concierto que ha tenido aquí lugar, se me presenta como la única apropiada para mis ideas (Günther 1963: 65).

Unas semanas más tarde, el bailarín recibe la respuesta de Schönberg.

Respecto a su pregunta he de decirle lo siguiente. Si conoce usted mi música y ha tenido en cuenta su casi total alejamiento respecto al mundo de la danza, y aun así la considera apropiada para sus ideas, entonces yo también la tomo como tal. Puesto que en este sentido yo mismo tengo mis ideas sobre el teatro, sería muy interesante conocer las suyas. Sin embargo, me encuentro ahora ocupado con otros trabajos, pero esto no ha de constituir un obstáculo, estoy en todo caso dispuesto a darle nombres de jóvenes músicos que buscan lo mismo que yo (Günther 1963: 65).

Ante esta situación, y el deseo de tener listo el ballet para la inauguración del Pabellón de las Artes en Stuttgart en marzo del año siguiente, Burger acude a Appia y a Dalcroze para dar con la música que necesitaba. El primero se encontraba enfermo y, a pesar de entusiasmarle las ideas de Burger, se ve obligado a declinar su colaboración. Lo mismo sucedería con Dalcroze, quien, sobrecargado de trabajos, no puede hacerse 
con otro más. El francés le recomienda a Albert Jeanneret, hermano de Le Corbusier. Aun habiendo encontrado músico, no hubo tiempo más que de presentar un pequeño esbozo para la inauguración del pabellón, una suerte de "ejercicio obligatorio con artistas soñadores, unos bailarines guerreros y unas floristas" (Günther 1963: 65).

Uno de los trabajos en los que había estado centrado Dalcroze, con la colaboración de Appia, era en la puesta en escena de la ópera Orfeo y Eurídice, de Gluck, estrenada en este mismo año en el festival de Hellerau. Escenarios simples, geométricos, vestuario sencillo y una coreografía donde los alumnos de Dalcroze ponían en práctica las ideas del maestro, supusieron de nuevo un hito en la danza moderna durante aquellos años. Años en los que podían ir viéndose también los trabajos de los coreógrafos Rudolf von Laban, ${ }^{17}$ su alumna Mary Wigman ${ }^{18}$ o Nijinsky. Este es el contexto para nuestro ballet en el mundo de la danza de principios de siglo.

En 1914 la guerra interrumpe la finalización definitiva del ballet. Schlemmer mantiene correspondencia con Burger durante sus años de soldado, y así, de forma epistolar en la distancia, continúan compartiendo las ideas a poner en práctica en el desarrollo del proyecto. Cuando el 7 de diciembre de 1916 Schlemmer recibe aquel permiso para pasar un día en Stuttgart, los Burger presentan una danza en tres piezas, a modo de pieza "piloto" de lo que sería el Ballet Triádico, acompañadas de la música de Marco Enrico Bosi, con el vestuario diseñado hasta aquel momento para la obra definitiva. Algunos entusiastas, como Hans Hildebrandt, deseaban que volviera a repetirse. Oswald Kühn, crítico del Schäbischen Merkur, supo valorar la línea de actuación del ballet y sus presupuestos estéticos. Incluso Leutnant Stotz, oficial de cultura del regimiento, organizó en otoño de 1917 un segundo festival para que hubiera una nueva representación, en la que Schlemmer pudo incluir una nueva pieza, Die Serenade mit langen Gitarre (Günther 1977: 51). A pesar de este reconocimiento, el pintor, recordándolo, cuenta decepcionado a Meyer-Amden haber experimentado el rechazo por parte del auditorio (Schlemmer 1989: 34). ${ }^{19}$ Este anticipo parecía anunciar un final próximo para los trabajos en la obra, pero su estreno definitivo no llegaría todavía, aún habría que esperar hasta 1922.

En otoño de 1919, Schlemmer se traslada al distrito Canstatt (Stuttgart), donde contará con una gran sala y un escenario real para continuar con sus trabajos. Una vez terminada la Guerra, éstos se llevan ahora a cabo con mayor intensidad, aunque no exentos de las dificultades derivadas del conflicto. Así lo contaba la que sería dentro de unos años la esposa de Schlemmer, Tut Schlemmer:

Era un trabajo en equipo, Oskar Schlemmer diseñaba los trajes y hacía los patrones, aun no teniendo idea de costura. La señora Burger cosía ella misma gran parte. Carl Schlemmer realizaba las partes plásticas de la decoración del escenario y se ocupaba de la ejecución técnica. El aprendizaje costó caro y hubo que superar grandes dificultades. En ese tiempo de posguerra se carecía de muchos materiales

17 Su notación aplicada a la danza, "cinetografía" o "notación Laban", propone la integración del espacio circundante del bailarín con sus gestos, cuyas direcciones se traducen sobre el papel en símbolos colocados en tres líneas, como notas en una partitura musical. Deseaba así ampliar la gama de movimientos de los bailarines respecto a las normas clásicas del ballet, para hacerlo más expresivo y creativo.

18 Sus coreografías aspiraban a ser la expresión del interior del bailarín. Un cuadro de Kichner, Totentanz der Mary Wigman (1926), la recuerda en una de ellas. El pintor escribió en su diario "la creación de un nuevo concepto de belleza está presente tanto en sus trabajos como en mis pinturas” (Henze 2016). 
y los que había eran muy caros. Se trataba de nuevos materiales para la época, alambres de níquel, objetos metálicos, que a Schlemmer le fascinaban. No había cristal flexible, ni celofán, ni aluminio, tampoco cremalleras, por lo que todos los trajes se abrochaban con mucha dificultad. Unos eran unidos con soldaduras, otros remachados o claveteados. Las formas hechas a base de papel maché eran pegadas con interminables tiras de papel de periódico (Scheper 1988: 26).

A lo largo de estos meses, Schlemmer llega a sentir ganas de abandonar el proyecto, tal como le cuenta a Meyer-Amden en sus cartas. Tiene claras sus ideas, su deseo es ponerlas en movimiento, y esto no le resulta difícil en sí mismo, pero considera cada vez más complejo el hacer que otros bailarines compartan y exterioricen sus mismas emociones. Llega a decir a su amigo si "no habrá cosas mejores que hacer que cortar faldas para ballet" (Scheper 1988: 26).

Los elementos más claros desde el principio, habían sido la historia, el argumento, $\mathrm{y}$, sobre todo, los personajes y sus figuras. El Ballet Triádico contaría la historia de una pareja, en los personajes interpretados por Burger y Hötzel, quienes, seducidos por un daimon, el propio Schlemmer, ${ }^{20}$ caen en la confusión perdiendo su inocencia primigenia. En distintos estadios la recuperarán, pero ahora de una forma, podría decirse, más elevada y enriquecida, pues lo que antes era una ingenuidad inconsciente, es ganada como una inocencia consciente de sí. A pesar de contar con una historia perfectamente trazada desde el comienzo, la puesta en escena, el diseño del escenario, los colores y formas del vestuario, la iluminación, serían objetos de numerosos cambios desde aquel 1912 hasta el estreno el 30 de septiembre de 1922. Estos cambios revelan cuál es el centro de las reflexiones de Schlemmer en la gestación y creación del ballet. No se trataba tanto del argumento, como del diseño visual de las formas, de la aplicación de los colores y su significado y, por ende, de la construcción de una atmósfera adecuada para sumergir al espectador en el acontecimiento puesto en movimiento sobre el escenario.

Se conservan diversos documentos en los cuales puede seguirse el trabajo de Schlemmer sobre el ballet, y reconocer, a partir de los cambios e incorporaciones respecto a la primera idea, esta evolución de sus preocupaciones al respecto y sus implicaciones en la obra final. En una carta a Meyer-Amden con fecha del 30 de noviembre de 1912, escribe un primer esbozo del plan para el ballet:

Preludio:

I. Gris, atmósfera polvorienta, antiguo vestuario de ballet, música convencional.

El rojo Revolucionario sale en un intenso y luminoso rojo, irradiando una luz brillante en forma de cuña.

II. Una figura vieja y nueva (blanca y roja), ensamblada en una forma cuadrada de color azul, y ésta a su vez en un triángulo azul.

El camino:

I. Una pared azul oscuro, figuras rojas y naranjas, un delirio dionisíaco, barbarie salvaje como fuente de fuerza (danza al modo de los pueblos exóticos).

II. Agotamiento. Una pared verde, figuras violetas y verdosas.

III. Locura: Avivamiento, éxtasis loco y sobreexcitado hasta los límites de lo posible. Vestuario alado, máscaras con sonrisas medievales y trascendentales. Pared amarillo limón, figuras grisáceas, azuladas. 
IV. Enajenación mental. Un ataúd... como decorado "y mientras no lo tienes, si la semilla no muere", tumba para la resurrección, una pared marrón, figuras grises y negras.

V. Resurrección. Dicha, atmósfera: una pared blanca, figuras azul claro y rosa claro. Nueva música.

Nueva danza.

Nuevo color (Scheper 1988: 18-19).

Al mes siguiente, Schlemmer ha pensado ya en modificar estas primeras ideas, los anota en su diario a finales de año, bajo el título "Evolución desde el antiguo al nuevo ballet". El planteamiento esquemático anterior cobra un carácter más narrativo, lo cual supone un mayor espacio para la historia, junto al ya contemplado para los colores y las figuras:

Telón: terciopelo oscuro; el derredor de madera natural color claro.

Lo gris: decoración convencional, quizá con luna, ¡como en una atmósfera vespertina! En la danza y la música: Finalización, como apoyo según las convenciones, corriente, ligeramente aceptable, estilo de los ballets rusos, a causa de su éxito. Los bailarines muestran el arte con el que podrían haber tenido éxito, seguramente sea del gusto del público.

Un daimon se desliza rápidamente sobre el escenario (corporeización de lo dionisíaco), un excitante color amarillo anaranjado, máscara, se pone a jurar, gesticulando delante del telón; los bailarines (interrumpidos en su danza) retroceden, se asombran. El telón se divide (o cae desde arriba una tela como un velo de color marrón oscuro, que envuelve a los bailarines y se va volviendo, poco a poco, más amarilla y roja). El daimon se esconde de nuevo. El ambiente tiene algo de oscuro, de búsqueda, de transformación; confusa y sorda, la melodía, la música y el tempo suben y bajan de nuevo, igual que sucede con los bailarines. La música, en los últimos registros, suena paralelamente color marrón. El daimon aparece de nuevo y con su aparición levanta el velo marrón. La atmósfera crece en adelante de roja a naranja oscuro. Música y danza provocan apasionadamente - éxtasis erótico, el daimon baila, triunfa. La atmósfera se intensifica cambiando desde el naranja hasta el amarillo limón como símbolo de lo enfermizo, irritante, extático, el movimiento de los bailarines y también la música son estridentes, con tonos altos.

Entonces: paralelamente cae la noche profunda - un fondo oscuro, los bailarines se cubren de gris. La música, profunda, en un tono menor, tristeza.

En medio del fondo aparece un punto violeta que se va convirtiendo en un círculo. El círculo se transforma en un cuadrado azul. La música se vuelve más clara - hasta el azul, un profundo y puro azul que lo domina todo. La música: mayestática, festiva, la danza lenta, delicada. Aparece el querubín (un ángel vestido de plata, muy vaporoso, tenue, delicado, con una silueta imprecisa). La atmósfera pasa del azul oscuro al azul claro, cada vez más clara hasta el blanco puro (o plateado) - los bailarines se reúnen, guiados por el querubín. Una estrella blanca brilla al fondo. La música suena suave (Schlemmer 1989: 6-7). ${ }^{21}$

Burger en una carta pone al corriente a Jeanneret acerca del tema del ballet, a la que sucedería otra misiva de Schlemmer sobre los detalles respecto al simbolismo de los tonos y colores. En esta relación se pone de manifiesto la importancia esencial de los colores en

21 Diciembre de 1912. 
el ballet hasta en los detalles a simple vista banales, como podrían ser el cromatismo de los telones que dividen las escenas:

Telón: blanco (como símbolo del comienzo, del devenir)

I. Una cortina violeta como símbolo de la confusión, de la apatía: Música y danza confusas, buscando (comienza un poco de melodía y se pierde de nuevo, lo mismo el tempo de la danza, amaga y desaparece de nuevo).

II. Telón rojo: como símbolo de la actividad, de la pasión despertada, de la sensualidad, algunas trompetas en la música (siempre que no esté limitada al piano).

III. Telón amarillo: símbolo de la trascendencia, atmósfera alocada y extática en la música y la danza.

IV. Tránsito al azul (telón azul): símbolo de la espiritualización, de la rememoración.

V. El telón azul: símbolo de la pureza, de la claridad, el color del cielo (Günther 1963: 65).

Esta evolución del plan cromático y su correspondiente ejecución material en el Ballet Triádico, en el que Jeanneret en respuesta a Burger afirma encontrar un tono demasiado filosófico al final de la pieza, cuenta con significativos precedentes. En primer lugar, enlaza con una idea ya trazada por el propio Kandinsky en 1909 y publicada en el Almanaque del Blaue Reiter en 1912 y conocida por Schlemmer. Nos referimos a Der gelbe Klang-ideada junto con otras tres piezas, Der grüne Klang, Schwarz und Weiss y Violet-, cuya descripción, perfectamente detallada por Kandinsky en el Almanaque, ${ }^{22}$ contiene grandes similitudes con las anteriores indicaciones dadas por Schlemmer para su ballet. Los colores y las luces, sus cambios y progresiones, son puestos igualmente en estrecho paralelo con el desarrollo musical ${ }^{23}$ a lo largo de los seis cuadros que componen la pieza. El propósito de Kandinsky es aquí mostrar un ejemplo de cómo, a pesar de que cada una de las artes se sirve de un medio externo diferente -el sonido, el color, o la palabra-, todas convergen en un punto común que las identifica: ser reconocidas como vibraciones, o experiencias interiores, en el alma del espectador y contribuir a lo que él llama "Verfeinerung der Seele", la mejora o sensibilización de su espíritu. Así, de la ópera toma la música como fuente del sonido interior; del ballet, la danza como movimiento abstracto; del sonido, su significado independiente y el potencial de su carácter autónomo. Además, esta interacción sinestésica entre las artes encontrará entre los profesores de la Bauhaus, no sólo a Kandinsky, sino también a otros adalides, como serían Itten o Gertrud Grunow. Por otro lado, Schlemmer conocía bien del mismo modo las experiencias sinestésicas de Skriabin, ${ }^{24}$ y sus asociaciones de tonos musicales a colores y efectos lumínicos.

Hasta ahora hemos hablado principalmente acerca del escenario y del diseño de la puesta en escena, pero, como decíamos, y nos indicaba Tut Schlemmer, la elabora-

22 La reproducción íntegra del Almanaque puede encontrarse en el alemán original en: Kandinsky, W., Marc, F. (eds.). 2016. Primera edición 1965. Der Blaue Reiter. Munich/Berlín: Piper, y también traducida al castellano en: Kandinsky, W., Marc, F. (eds.) 2010. El jinete azul: Der Blaue Reiter. Barcelona: Paidós.

23 Se había previsto que la música fuera compuesta por Thomas von Hartmann y que las piezas fueran estrenadas en 1914, el estallido de la guerra lo impidió.

24 Para su Prométhée. Le Poeme du feu introdujo un parte para un piano al tocarse que pudiera combinar música y luz. Fue creado por Alexander Moser. De uso privado, se ignora si funcionó, hoy existe un modelo en el Museo Skrjabin. Esta parte de la obra se interpretó en 1915 con la "cromola" de Preston S. Millar, sin el éxito esperado. Desde entonces se ejecuta sin los efectos lumínicos pensados por el compositor. 
ción del vestuario resultó esencial. Al igual que sucede con el resto de los elementos espaciales y ambientales del ballet, no resulta en absoluto accesorio, sino crucial en el desarrollo integral del conjunto y en su significación visual. De hecho, las ideas sobre las atmósferas formuladas hasta ahora, encuentran su origen en la configuración de las formas para los figurines del vestuario. Así se lo explica Schlemmer en carta a Hildebrandt: "Primero fue el vestuario, los figurines. Después se buscó la música. [...] A partir de la música y los diseños del vestuario se desarrolló la coreografía" (Schlemmer 1989: 98). ${ }^{25}$

En otra de sus cartas refiere igualmente esta relevancia capital del vestuario, aquí como diferencia sustancial entre su forma de entender la danza y la del Dalcroze. En tanto que la de éste, a los ojos de Schlemmer, es un ejercicio de escuela, "una danza ética", con significaciones "básicas y bellas", su voluntad es en cambio "estética, mejor dicho, artística. [...] Dalcroze no tiene vestuario, o depende de los diseños de Hodler. Para mí el vestuario lo es todo" (Scheper 1988: 27). Y es que el vestuario para Schlemmer constituye un compromiso con la expresión de un ideal de belleza artística autónomo, sin otra finalidad que el arte en sí mismo (Schlemmer 1927b).

Tanto el color como la geometría, son los elementos a partir de los cuales Schlemmer elabora toda una gramática aplicada al diseño de los diferentes trajes para los bailarines. Ésta cobrará su sentido en la combinación entre los movimientos de la danza y las formas geométricas con las que están vestidos quienes los ejecutan, quedando así convertidas en formas vivas y dinámicas. Ello sin descuidar, al mismo tiempo, la contextualización de sus gestos en la atmósfera lograda gracias al cuidado diseño del resto de la escena. El predominio de los valores geométricos en los modelos para el vestuario, queda ya reflejado en una de las notas de su diario en octubre de 1915:

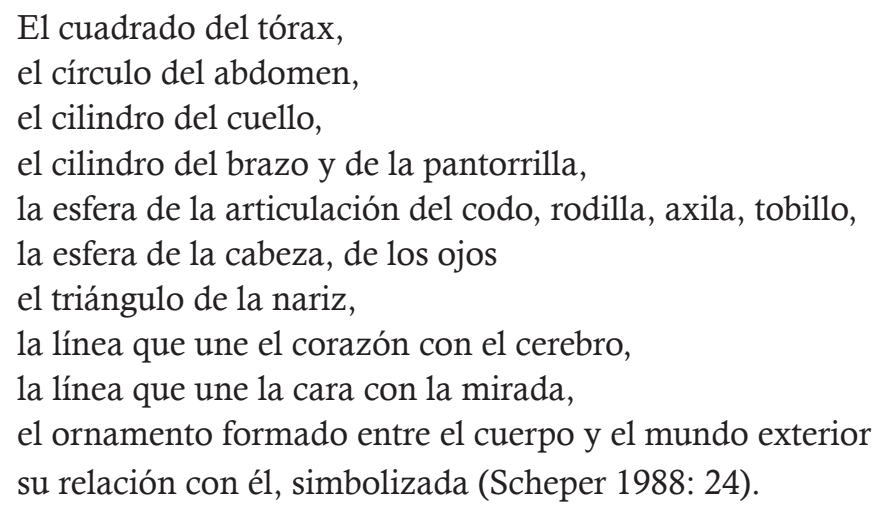

La interacción de estas formas dotadas de vida a través de la danza, articuladas únicamente mediante su movimiento específico y el sonido de la música, sin intervención de las palabras, no es sino lo propio de la pantomima, género en el cual Schlemmer -igual que Burger- ve el despliegue de infinitas, y deseadas, alternativas para la renovación del panorama escénico de la época. De un modo quizá similar a cómo venían haciendo ya las Ausdruckstänzerinen arriba mencionadas, pero incorporando la estética del arte coetáneo, del Expresionismo, del Futurismo y del Cubismo fundamentalmente. Las razones se las da Schlemmer a su amigo Meyer-Amden: "Veo grandes posibilidades en el ámbito del ballet gracias a la pantomima por su independencia 
respecto a lo histórico, lo que la diferencia del teatro y la ópera, por eso creo que de este pequeño pero libre ámbito de la escena surgirán novedades decisivas" (Scheper 1988: 25).

En aquella misma carta desvela el origen de su entregado trabajo a la creación de este ballet, incluso viviendo inmerso y de forma activa en un conflicto bélico. Desde aquel 1912 descubría, gracias a este proyecto, cuál es para él el medio más inmediato de expresión artística y, podríamos decir, el más completo: el cuerpo humano, y éste en su interacción con el espacio tridimensional. El acontecimiento estético limitado al plano en un lienzo, o al estatismo de una escultura, eclosiona y cobra vida si las formas pictóricas y plásticas se ponen en movimiento "encarnadas" en la figura humana sobre un escenario, y si se ofrecen, no únicamente a la experiencia del ojo, sino también a la del oído gracias al acompañamiento musical.

De esta manera, un diseño global de la escena bajo dichos parámetros no sólo pone en juego los elementos artísticos esenciales, como la línea o el color, sino que además hace desaparecer la ficción de la tridimensionalidad propia de la pintura tradicional, y ya no con los recursos propios del arte abstracto, es decir, prescindiendo de los tonos de color y de la perspectiva, sino incorporando la auténtica tercera dimensión a las imágenes al colocarlas sobre el escenario. Elimina a su vez otro efectismo ilusorio, el de la luz y los tonos de color, incorporando ambos como elementos reales. Al mismo tiempo, suma a la presencia de las formas en el espacio, común tanto a la pintura como a la escultura, su desarrollo en el tiempo gracias a la música y al movimiento de la danza. Schlemmer describe estos fenómenos a Meyer-Amden, hablando de la existencia de una "geometría en el suelo sobre el que se danza" como "parte y proyección de la estereometría espacial", a lo que añade cómo él mismo práctica al piano incluso "una geometría similar de los dedos y el teclado", esforzándose por encontrar "una identidad y unidad entre el movimiento, la forma de los cuerpos y la música" (Schlemmer 1989: 62). ${ }^{26}$

Podríamos ver aquí la aspiración hacia la Gesamtkunstwerk, a la "obra de arte total", idea gestada ya durante el Romanticismo, donde las figuras del filósofo, el poeta y el artista se confunden, y que llega a su culminación con Wagner. Para él, la danza, la música y la poesía eran tres artes inseparables, porque el hombre es cuerpo -que se mueve y se ve-, sonido - que se escucha en su voz-y palabras - de las que se sirve para expresarse (Wagner 2007). Entiende el arte como la actividad más elevada del hombre, y el arte escénico, la unión más íntima, excelsa y perfecta de todas las artes (Wagner 2013: 36). En el caso de Schlemmer, éste no busca satisfacer el deseo por alcanzar esa "obra de arte total" reuniendo las artes en un único golpe de expresión, sino involucrando la propia vida del artista en la obra hasta un punto tal, que llega a integrarse en ella, y ella en él. La experiencia vital del artista se convierte en el corazón de la verdadera obra de arte total, en palabras de Schlemmer, en el "símbolo de la unidad entre la naturaleza y el espíritu" (Scheper 1988: 34).

\section{Das Triadische Ballett y la Bauhaus}

Esta concepción interdisciplinar y complementaria de las artes es la que quizá le lleva a visitar y a conocer más de cerca, en 1920, lo que se venía haciendo en la recién inaugurada Bauhaus. Al regresar de aquel viaje a Dresde, donde exponía con Baumeis- 
ter en la Galería Arnold, decide pasar por Weimar y conocer la escuela a la que seguía con interés desde que Gropius publicara aquel manifiesto fundacional en 1919. A la primera invitación del arquitecto a formar parte del profesorado, Schlemmer contesta con una negativa, argumentando trabajos pendientes por terminar, es decir, el Ballet Triádico era aún su prioridad. Finalmente, ante la insistente llamada de Gropius, quien volvería a invitar a Schlemmer en octubre, llegan a un acuerdo. Firmará su contrato en diciembre, y comenzará su trabajo en 1921, permitiéndosele vivir entre Weimar y Stuttgart para terminar el ballet.

Esta unidad entre las artes, existente en el sistema pedagógico y estructura vital de la Bauhaus que admiró a Schlemmer, se ajustaba perfectamente a su idea acerca del hombre, del arte, del artista y de la relación entre ellos, concentrada de forma representativa y simbólica sobre el escenario y en la reunión de la superabundancia de los recursos escénicos, como venimos viendo. Así lo deja de manifiesto, ya como profesor integrado en la institución, en sus reflexiones antropológicas y estéticas:

La historia del teatro es la historia de la transformación de la figura del hombre: el hombre como representante de acontecimientos corporales y espirituales en proceso de cambio desde la ingenuidad a la reflexión, de la naturalidad a la ficción. Forma y color son los medios de este cambio, los medios del pintor y del escultor. El escenario de dicha transformación es la estructura formal del espacio y de la arquitectura, el trabajo del arquitecto. Por ello, el papel del artista, quien sintetiza estos elementos, se confirma en el ámbito de la escena (Schlemmer 1925b: 7). ${ }^{27}$

Esta nueva ocupación en la Bauhaus, junto con nuevos trabajos como escenógrafo, concretamente en el acondicionamiento del teatro de Württemberg para el estreno de las obras de Paul Hindemith, con textos de Kokoschka, Mörder, Hoffnung der Frauen y Nuschi-Nuschi, demorarían un par de años más el estreno definitivo de Triadisches Ballett, que no tendría lugar hasta aquel 30 de septiembre de 1922 en el Württembergischen Landestheater.

Los espectadores que tuvieron ocasión de acudir al estreno se encontrarían, en primer lugar, con un título cuanto menos insólito. El prefijo "tria-", se refiere a la tríada de notas que forman un acorde. Schlemmer llegaría a describir el ballet como una "apoteosis de la ternalidad" (Scheper 1988: 34), "una tríada en figuras, formas y colores. [...] Una obra colectiva a partir de la pintura y la plástica, la danza y la música" (Schlemmer 1925a: 191). Y es que para nuestro artista "el tres es una figura dominante y eminentemente importante en la cual el yo monomaníaco y la oposición dualista son superados y comienza la colectividad" (Scheper 1988: 34). Según este planteamiento, la obra pretende la superación del yo individual y de su enfrentamiento al otro en la dualidad, mediante la combinación de elementos reunidos en tríadas a través de la creación artística, conectando todos sus puntos creador, bailarines, coreografía, escena, música y público, y aspirando así alcanzar esa realidad colectiva. Un deseo para cuyo cumplimento se precisa la implicación más plena posible por parte del espectador, otra razón por la cual la obra invita a la participación simultánea de la vista y el oído. Este anhelo de cómplice plenitud es el origen, por tanto, de la presencia constante del número tres. Tres son las series en que se divide el ballet: la serie amarilla, alegre,

27 Los Bauhausbücher, editados por Gropius y Moholy-Nagy se publicaron desde 1925 hasta 1930, con un total de 14 números. 
burlesca y cómica; la serie rosa, festiva y semi-seria; la serie negra, mística, fantástica y seria. Asimismo, el ballet se apoya en tres elementos, la combinación entre vestuario, coreografía y música; al igual que la puesta en escena se articula a partir del espacio, la forma y el color. A ello se suman las tres dimensiones del escenario y las tres formas básicas de la geometría, en las que se basan tanto los trajes como las diferentes partes del decorado: el triángulo, el círculo y el cuadrado. Formas estrechamente vinculadas aquí, por otra parte, a los tres colores también básicos, el rojo, el azul y el amarillo, presentes en todo el diseño.

En segundo lugar, la música, estímulo para el movimiento de estas formas y colores, que escuchó aquel auditorio, no fue finalmente compuesta por Jeanneret, tampoco por los demás músicos con los que Burger contactó buscando al compositor ideal, como August Halm, o Waldemar Schmidt, quien llegó a proponerse por propia iniciativa (Günther 1977). También Paul Hindemith se ofrecería en julio de 1920 a comprometerse con la musicalización. Realizó tres composiciones diferentes, que Schlemmer descartaría, pues hubieran ofrecido dificultades a los bailarines en la coreografía. ${ }^{28}$ Finalmente se utilizaron piezas tanto de compositores contemporáneos, como Mario Tarenghi, Bossi, Debussy, así como de otros clásicos, Haydn, Mozart, Pietro Domenico Paradies, Baldassare Galuppi o Händel. ${ }^{29}$ Esta inseparable imbricación entre el sonido y las formas dinamizadas sobre el escenario en los gestos y movimientos de los bailarines, quedaba descrita por el propio Schlemmer como una de las cualidades especiales del Ballet Triádico: "El valor de este ballet reside en la musicalidad de la organización de las formas [...] surgidas del deseo de jugar con ellas, con los colores y el material. ¿No son esfera, semiesfera, cilindro, disco, espiral, elipse, etc., las formas espaciales de la danza, los elementos de movimiento y rotación por excelencia?" (Schlemmer 1927a: 523). La música adquiere así su forma y dinamismo plenos en el acontecimiento sobre el escenario.

Este público había contado con la introducción escrita por el propio Schlemmer al especial ballet que iban a contemplar, o mejor dicho, vivir, "un trabajo común de entusiastas solícitos que han querido contribuir a dar forma a una idea". Y esta idea no es otra que la de lograr algo, dice, "poco común: unidad y compenetración entre todos los elementos de la danza, los movimientos del cuerpo, espacio, vestuario, forma y color" (Scheper 1988: 33) ${ }^{30}$ El medio para ello era la introducción del arte moderno, al que atribuye la tarea de "indicar el camino a la danza y darle la fuerza elemental", "casi todas las orientaciones de la pintura moderna, Cubismo, Futurismo, Expresionismo, Suprematismo, Surrealismo, Constructivismo, experimentan su reflejo, a veces incluso su plenitud, en el ámbito escénico" (Schlemmer 1927a: 521). El resultado, "una fiesta del color y de la forma" (Scheper 1988: 33).

Sin embargo, todo el esfuerzo puesto en este proyecto durante 10 años, no fue

28 Hindemith llegó a componer la música para la puesta en escena del Ballet Triádico que tuvo lugar en el Festival de Música de Cámara Donaueschingen en 1926, representado allí a invitación del compositor. Realizada para ser ejecutada en un órgano mecánico.

29 Según Vinzenz (2018: 198), la representación comenzaría con la obertura del Titus de Mozart. Para las cinco danzas de la serie amarilla se utilizaron una pieza de Tarenghi, tres de Bossi y una de Debussy. Haydn acompañaría la primera danza de la serie rosa y Mozart la segunda y tercera danza de esta serie. Para las danzas de la serie negra se interpretaría a Haydn, Paradies, Galuppi y Händel, en este orden. Con orquesta sonaron únicamente la segunda danza de la serie rosa de Mozart y la primera de la serie negra de Haydn, el resto de las piezas escogidas -de las que no constan los títulos-se interpretaron al piano (Scheper 1988: 298). 
tomado en serio por la crítica tras el estreno, sino como una mera chanza, fruto de la imaginación desorbitada de un artista. Así, por ejemplo, en el Württembergischen Zeitung del 2 de octubre de 1922, se lee: "Las máscaras de baile de Schlemmer son, sin excepción, producto de una fantasía de artista fecunda y llena de humor. Estos títeres de madera, personajes inquietos y agitados, borlas, bolas doradas, discos de colores, ejercen inmediatamente su efecto sobre los músculos de la risa" (Günter 1978: 97).

La obra pasa prácticamente desapercibida, como un evento local, excepto para un grupo especial del auditorio. Como Schlemmer ya trabaja por entonces en la Bauhaus, un grupo de alumnos asisten junto con Gropius al estreno. Entusiasmados por el resultado, los alumnos piden a Schlemmer una puesta en escena en Weimar, en la semana del ballet de la Bauhaus. Dicha representación tiene lugar el 16 de agosto de 1923, obteniendo un éxito considerable.

Esta es la razón por la que la relación entre Schlemmer y Burger iría rompiéndose paulatinamente, pues el Ballet Triádico comienza así a considerarse obra únicamente de Schlemmer, y creación nacida en el seno de la Bauhaus. El pintor buscaba siempre dejar claro que la obra pertenecía a ambos, pero la realización de los carteles donde aparecían sus nombres, y se describía su participación en el ballet, no siempre dependía de él. Burger decide distanciarse definitivamente del proyecto a partir de las representaciones sucesivas que tendrían lugar en Dresde en ese mismo 1923 y a partir de 1924 hasta 1932 en Hannover, Frankfurt, Bremen, Donaueschingen, Dessau o Berlín y finalmente en París.

De manera que, aun siendo el Ballet Triádico una creación anterior a la Bauhaus, son Gropius y sus alumnos los que ven sus posibilidades, los que reconocen su novedad y las aportaciones de sus conceptos, no sólo al mundo de la escena, sino también al de las artes en general, en la gramática de la forma, del color, del movimiento y en la integración en ellos de la figura humana y de la música. Igualmente, saben confirmar las fuentes de inspiración artística para el ballet, las nuevas corrientes artísticas modernas que ellos mismos conocían y desarrollaban. Y es también gracias al impulso concedido desde Bauhaus para sucesivas representaciones, como esta obra encuentra el eco esperado entre el público y la crítica. Todo ello sin pasar por alto que Schlemmer se hace cargo, como dijimos, del teatro de la institución, siendo bajo su dirección una de las secciones más activas de la casa. Por estas razones, no es de extrañar que el nombre de este ballet esté siempre vinculado, de un modo u otro, a la Bauhaus, además de porque las audacias formales y estéticas en él planteadas se encuentran como ante un espejo frente a la propuesta pedagógica y creativa del proyecto de Gropius.

\section{El ballet de Schlemmer y el siglo XXI}

Desde aquel 1932, cuando tiene lugar en París la última representación antes de la desaparición de la Bauhaus, la primera vez que se realiza una nueva puesta en escena del Ballet Triádico es en 1977, ${ }^{31}$ en la "Berliner Festwoche", de la mano del bailarín y coreógrafo Gerhard Bohner. Un trabajo nada fácil, pues de los 18 trajes originales,

31 En 1970 Margarete Hastings realizó una reconstrucción grabada para la televisión alemana basándose en documentación, textos, e imágenes originales. Margarete Hastings, Franz Schömbs, Georg Verden (coreografía según Oskar Schlemmer), John Halas (dir.), Edith Demharter, Raphl Smolik, Hannes Winkler (bailarines), Erich Ferstl (música, según P. Hindemith). 1970. Das Triadische Ballett: Ein Film in drei Teilen. Stuttgart: Bavaria Atelier GMBH/Stuttgart Ballett. 
se conservan únicamente $6 ;^{32}$ y respecto a las coreografías, no existen más que dos referencias precisas de las doce danzas -cinco, tres y cuatro respectivamente para cada una de las tres partes- que componen el ballet, junto con los documentos y artículos redactados por Schlemmer conteniendo sus ideas genéricas respecto al movimiento y la danza. Estas dos fuentes principales son: una breve descripción recogida en una carta dirigida por Schlemmer al pintor y compositor Alexander Rath en 1926, ${ }^{33}$ y otra descripción fechada en 1927, ${ }^{34}$ enviada al director de orquesta Hermann Scherchen, quien estuvo interesado en la posibilidad de dirigir una representación del ballet. Con dichas dificultades se enfrentaba Bohner, quien, no buscando reproducir literalmente la representación original conforme a las fuentes, supo, según la crítica, conservar el espíritu global del ballet, tanto en el diseño del vestuario, a cargo de Urlike Dietrich, como en los movimientos de los bailarines. Sin embargo, la música continuaría siendo el caballo de batalla principal. La compuesta esta vez por Hans-Joachim Hespos, no lograba fundirse en un todo con lo sucedido en el escenario, como fue siempre la aspiración de Schlemmer, parecía más bien conservar su carácter independiente y de acompañamiento, según nos dice la crónica de la época de Hartmut Regnitz (Regnitz 1977: 29).

Una de las últimas coreografías ha sido elaborada en el "Theater der Klange" en 2015 y ha corrido a cargo de Jacqueline Fischer, bajo la dirección de Jörg Udo Lensing, autor también de la escenografía y parte del vestuario, con música de Thomas Wansing. En 2017 se renovó el vestuario para ponerla de nuevo en escena, y celebrar así el 30 aniversario de la especial preferencia de esta compañía por la Bauhaus como fuente de inspiración. Ya en sus orígenes, en 1987, reconstruyeron la pieza Das mechanische Ballett, ideada por los alumnos de la Bauhaus Kurt Schmidt y Georg Teltscher en 1923, año en que, recordemos, comenzaba la labor de Schlemmer como director del teatro de la Bauhaus. Esta obra ha estado en el repertorio del "Theater der Klange" durante treinta años, con más de 200 representaciones en giras por todo el mundo. Trias, nombre que dieron a su particular reconstrucción del Ballet Triádico, no hacía sino continuar la huella dejada por la Bauhaus sobre el diseño en el mundo de la escena y la danza.

Los últimos testigos de esta actualidad de la Bauhaus son los bailarines del "Bayerischen Junior Ballett München", quienes, desde 2014, han realizado ya diversas representaciones, y aún en 2019, pueden seguir viéndose en el Theaterhaus de Stuttgart, la ciudad que lo vio por primera vez.

Así pues, el papel de Schlemmer en la actualidad de la Bauhaus no parece cesar. Las puestas en escena de su Ballet, ya inseparable de la realidad de esta institución nacida ahora hace 100 años, le darán vida en cada ocasión, de forma siempre renovada, pues una puesta en escena es siempre, como decíamos al comienzo, un acontecimiento revivificado con cada representación. Por otro lado, el hecho de que siga siendo objeto

32 Tras la ruptura, Burger y Schlemmer se repartieron el vestuario. Schlemmer se quedaría con los seis que llevara en la representación de Stuttgart, el resto pasarían a ser propiedad de Burger. Desaparecieron en el incendio que tuvo lugar en el Kunstgebäude de Stuttgart durante la Segunda Guerra Mundial, en 1943, donde Burger tenía su escuela de danza.

33 Bauhaus-Archiv, Berlín. Alexander Rath fue alumno de la Bauhaus desde 1920, escribió a Schlemmer interesándose por la cuestión de no haber sido finalmente compuesta una música específica para el ballet.

34 Bauhaus-Archiv, Berlín. En este caso, la misiva incluye dibujos y acuarelas con los figurines y diversos esquemas, así como anotaciones e indicaciones escritas a mano por Schlemmer. 
de interés, que sea estudiado y trabajado reiteradamente en el mundo de la danza y del teatro, es sintomático de su carácter universal y atemporal, no adscrito con fecha de caducidad a una época y lugar concretos. Sorprendente en todas sus dimensiones, continúa desplegándose como potencial material de trabajo para presentes y futuros artistas, y objeto de gozo estético para los espectadores que deseen, aunque solo sea, aspirar a cumplir las esperanzas de Schlemmer.

El Ballet Triádico, en su forma actual, no es más que el comienzo, una etapa (para mí). ${ }^{35}$ Las ideas para un ballet cómico, y al mismo tiempo trascendental, están dispuestas. Más y mejores bailarines, medios para la creación de los figurines, una música más perfecta; estas son mis esperanzas (Schlemmer 1989: 98).

Esperanzas por lograr poner sobre el escenario con formas, colores, luces, gestos, música, movimiento, su idea del "hombre como acontecimiento, como el ser capaz de lo inmediato, el mediador, el transmisor del lenguaje, de la palabra, de la música", en un espacio que hace posible ver "su transformación, sus cambios, su disfraz a través del vestuario y de la máscara, su reflejo en muñecos sin vida, en las figuras mecánicas, en las marionetas, y con ello la superación de la forma" (Schlemmer 1927a: 524). Una concentración de fenómenos que pueden parecer irrealizables, él mismo se lo llega a preguntar retóricamente "¿Utopía? [...] La escena comienza con la transformación interior del espectador, el hombre como el alfa y la omega de toda condición del hecho artístico. [...] Seguirá siendo una utopía, en tanto que no encuentre una disposición espiritual" (Schlemmer 1925b: 20). El Ballet Triádico parece que seguirá entonces vivo mientras haya espíritus inquietos, como sus bailarines, que deseen corresponder a esta disposición interior y profunda para con el hecho artístico.

\section{Bibliografía citada}

Appia, A. 1924. "Theatrical Experiences and Personal Investigations", (ensayo inédito

(1924?) Yale: Appia Collection, Beinecke Library, Yale University, p. 383, citado

en: Beachman, R. 1985. "Appia, Jacques Dalcroze and Hellerau. Part One: 'Music

Made Visible"” en: New Theater Quarterly, vol. 1, núm. 02, mayo 1985, pp. 154-164.

Beachman, R. 1985. "Appia, Jacques Dalcroze and Hellerau. Part One: 'Music Made

Visible"” en: New Theater Quarterly, vol. 1, núm. 02, mayo 1985.

- 1994. Adolphe Appia: Artist and Visionary of the Modern Theatre. Oxon/Nueva

York: Routledge.

Dalcroze, E-J. 1920. Le Rythme, la musique et l'education. París: Libraire Fischbacher

Demuth. V. 2002. Topische Ästhetik: Körperwelten, Kunsträume, Cyberspace. Würzburg:

Königshausen \& Neumann Verlag.

Günther, H. 1978. "Die Triadische Legende", en: Stuttgarter Zeitung, 14 de enero de 1978, p. 97.

— 1977 . "Die Stuttgarter Landsleut' des Oskar Schlemmer", en: Stuttgarter Zeitung, 9 de julio, 1977, p. 51.

— 1963. "Von dämonischen zum Triadischen Ballett", en: Sonntagsbeilage zur

Stuttgarter Zeitung, 6 de julio de 1963, p. 65.

Henze, W. 2016. Ausstellung: Totentanz. Werke Ernst Ludwig Kirchners zu Mary Wigman.

35 Entre paréntesis en el original. 
Kleines-Katalog. Wichtrach/Bern: Galerie Henze \& Ketterer, disponible en: http:// www.henze-ketterer.ch/de/ausstellungen/aktuell/wichtrachbern/a114-totentanz/ [consultado el 26 de mayo de 2019].

Kandinsky, W., Marc, F. (eds.). 2016. Primera edición 1965. Der Blaue Reiter. Munich/ Berlín: Piper.

Maur, K. v. 1977. Oskar Schlemmer. Der Maler, der Wandgestalter, der Plastiker, der Zeichner, der Graphiker, der Bühnengestalter, der Lehrer. Stuttgart: Württembergischer Kunstverein. Catálogo correspondiente a la exposición en torno a Oskar Schlemmer en la Staatsgalerie de Stuttgart (11.08-18.09.1977).

Meyer, H. 1928. "Bauhaus und Gesellschaft", en Bauhaus. Zeitschrift für Gestaltung, año 3, núm. 1, enero de 1929.

Regnitz, H. 1977. "Getanzte Raumphysik. 'Triadisches Ballett' in Berlin wiederaufgeführt", en: Stuttgarter Zeitung, 8 de septiembre, 1977, p. 29.

Scheper, D. 1988. Oskar Schlemmer. Das Triadische Ballett und die Bauhausbühne. Berlín: Akademie der Künste.

Schlemmer, O. 1989. Oskar Schlemmer. Idealist der Form. Briefe. Tagebücher. Schriften. Leipzig: Reclam Verlag.

— 1927a. "Ausblicke aus Bühne und Tanz", en: Melos, núm. 12, diciembre, 1927, pp. 520-524.

—, 1927b. "Mechanisches Ballett", en: Gentges I. 1927. Tanz und Reigen. Berlín: Bühnenwolksbundverlag, pp. 80-83.

—, 1925a. "Der theatralische Kostümtanz", en: Einstein, C., Westheim, P. (eds.) (1925/reimpresión 1984). Europa Almanach 1925. Leipzig: Kiepenheuer Verlag, pp. 189-191.

—, 1925b. "Mensch und Kunstfigur", en: Gropius, W., Moholy-Nagy, L. (eds.) 1925. Die Bühne im Bauhaus. Munich: Albert Langen Verlag, pp. 7-43.

Simonson, M. 2013. Body Knowledge: Performance, Intermediality, and American Entertainment at the Turn of the Twentieth Century. Nueva York: Oxford University Press.

Vinzenz, A. 2018. Vision "Gesamtkunstwerk": Performative Interaktion als künstlerische Form. Bielefeld: Transcript Verlag.

Wagner, R. 2007. La obra de arte del futuro. Valencia: Universidad de Valencia. , 2013. Arte y Revolución. Madrid: Casimiro Libros. 


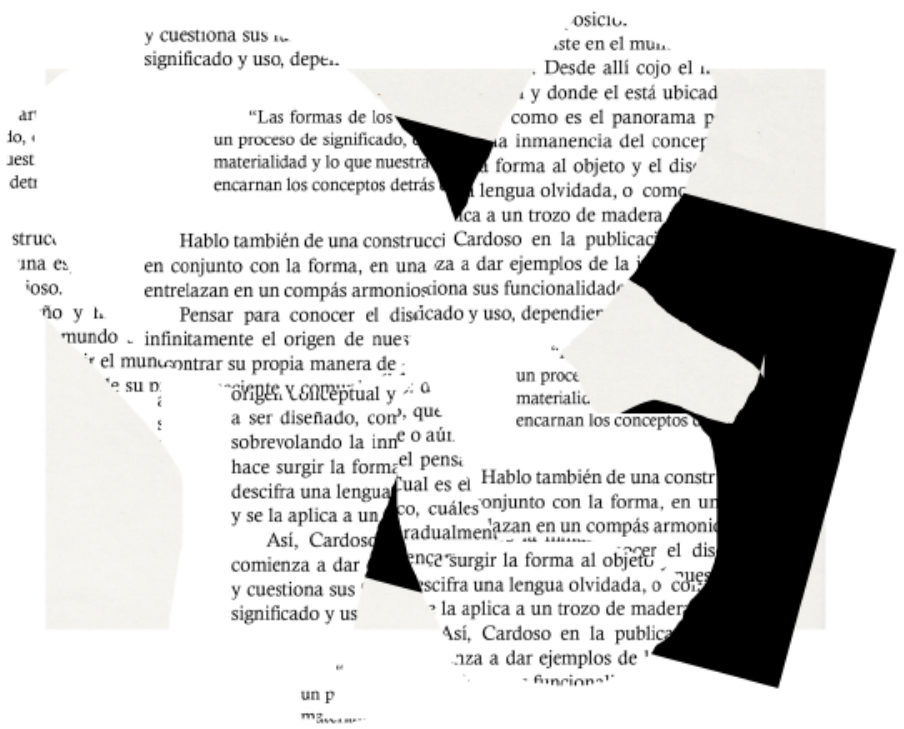

"Lo impreso exige una humildad de espíritu por cuya falta muchas de las bellas artes se tambalean ahora en experimentos de autoconciencia y sensiblería. No hay nada simple ni aburrido en lograr una página transparente. La ostentación vulgar es el doble de fácil que la disciplina".

Beatrice Warde, The Crystal Goblet, or why printings should be invisible (1930)

"El diseño que es objetivo, comprometido con el bien común, bien compuesto y delicado, constituye la base del comportamiento democrático".

Josef Müller-Brockmann, Grid and Design Philosophy (1981) 

EDITA

\section{SEyTA.}

SOCIEDAD ESPAÑLAA
DE ESTETICA Y TEORIA DE LAS ARTES

CON LA COLABORACIÓN DE

\begin{tabular}{|c|c|c|}
\hline 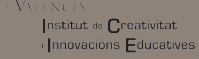 & $\begin{array}{l}\text { VNIVIRSIIN } \\
\text { II) VIIINCL Departament de Filosofia }\end{array}$ & 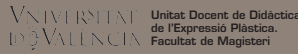 \\
\hline $\begin{array}{l}\text { ESTETICA } \\
\text { FLOSOFIA }\end{array}$ & 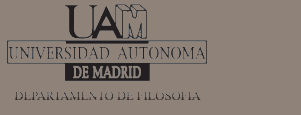 & $\begin{array}{l}\text { UAB } \\
\begin{array}{l}\text { Universitat Autònoma } \\
\text { de Barcelona }\end{array}\end{array}$ \\
\hline
\end{tabular}

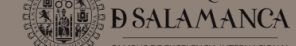

https://ojs.uv.es/index.php/LAOCOONTE/index 